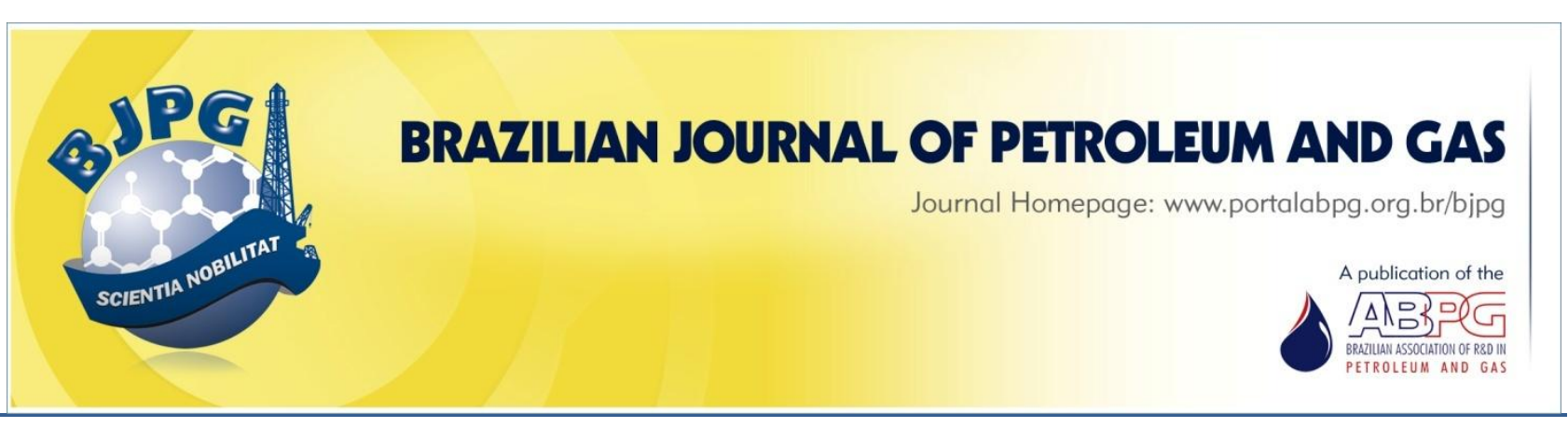

\title{
OPTIMIZATION OF BIODIESEL PRODUCTION FROM FRYING OIL AND BOVINE TALLOW
}

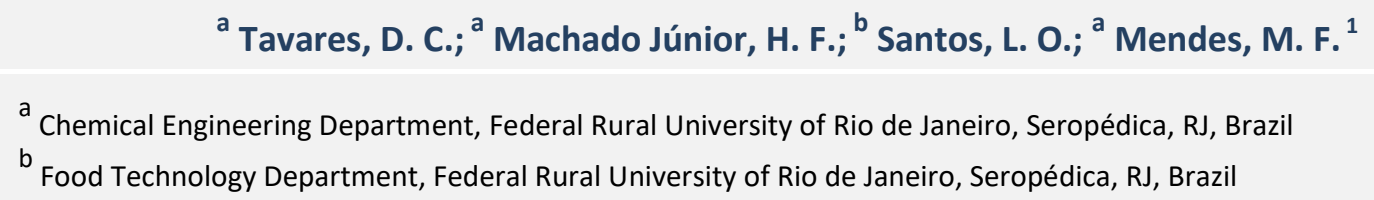

Received: 25.10.2016 / Revised: 24.06.2017 / Accepted: 30.06.2017 / Published on line: 18.07.2017

\begin{abstract}
Nowadays, discussions about energy-related issues are in evidence. The dynamics of gradual depletion of non-renewable energy reserves, such as oil ones, and global warming have encouraged the search for renewable energy alternatives. The main objective of this work is to evaluate the influence of major operational variables on the transesterification reaction of mixtures of frying oil and bovine tallow, in the presence of methanol, using microwave technology. In an effort to optimize biodiesel production, a statistical design was performed, considering the solvent/feed ratio, the ratio between frying oil and bovine tallow, the amount of $\mathrm{KOH}$, reaction time, and temperature as independent variables. The dependent variables analyzed were biodiesel yield and esters content, obtained by chromatographic analysis. The experiments and the analysis confirmed that a 9:1 solvent/feed molar ratio of, $1.5 \%$ catalyst, 35 seconds reaction time, and a mixture containing $70 \%$ of frying oil and $30 \%$ of bovine tallow provided yields above $89 \%$. The best conditions to reach $99.43 \%$ of ester content used a 9:1 solvent/feed molar ratio, $0.5 \%$ catalyst, $70 \% / 30 \%$ frying oil/bovine tallow, and 35 seconds reaction time.
\end{abstract}

\section{KEYWORDS}

biodiesel; frying oil; bovine tallow; methanol; microwave

\footnotetext{
${ }^{1}$ To whom all correspondence should be addressed.

Address: Chemical Engineering Department, Federal Rural University of Rio de Janeiro, Seropédica - RJ, Brasil.

ZIP Code: 23897-000 | e-mail: marisamf@ufrri.br

doi:10.5419/bjpg2017-0006
} 


\section{INTRODUCTION}

The global economy has become more dependent on the energy's market. The increase in economical development has a direct relationship with higher energy demands. Thus, the energy matrix, and the dynamics for new energy sources are becoming essential for economic agents such as businesses, governments, or individuals.

In this context, biodiesel is a source of renewable energy and because of that, it can be observed the increase development in its market. To achieve this target, a growing number of feedstocks are used as raw materials in biodiesel production. Biodiesel is produced by the transesterification of triglycerides with short chain alcohols, such as methanol or ethanol, usually catalyzed by an acid or a base.

Likewise, in Brazil, the use of biodiesel plays a promising role in the Country's energy scenario. It contributes to the economy by creating jobs in the primary sector, which are important to the Country's social development, and is priority of the current government administration (UBRABIO, 2016).

Raw materials used in the production of biodiesel are vegetable oils, animal fats, and waste oils and fats. These materials have triglycerides, glycerol, esters, and fatty acids in varied proportions. Monoglyceride or diglyceride esters are obtained from the direct esterification of fatty acids, meaning that the solution has some esters differing in concentration and type (Gazzoni, 2012).

It is important to provide an overview about the potential of vegetable oils for biodiesel production, especially with regards to the technological and economic aspects of this process. However, the major obstacle in the commercialization of biodiesel production from edible vegetable oil is its high production cost. Raw material costs account for almost $59 \%$ of the biodiesel production total cost. The choice of raw material for biodiesel production relies largely on geographical factors. Depending on the nature and quality of the raw material, changes in the production process may be required (Zhang et al., 2003). However, there are some alternative raw materials that can be used for biodiesel production, like frying oil and bovine tallow. Waste cooking oil and fats are promising alternatives for edible vegetable oil, because they pose significant disposal problems in many parts of the world (Mohammadshirazi et al., 2014).

Moreover, bovine tallow is an inexpensive commodity for biodiesel production in Brazil (Oliveira, 2004). Brazil has produced around 650,000 ton of bovine tallow per year. Because in recent years the Country has increased its meat production, Brazil has satisfactory amounts of beef tallow that can be used as raw material in biodiesel production (SBRT, 2016). According to Mendonça et al. (2011), Brazil is the world leader in exportation of beef and has one of the world's largest cattle inventory. Therefore, biodiesel production from beef tallow, a byproduct of the beef industry, is not only viable from a raw material supply standpoint, but it has an environmental importance, since most of the beef tallow is, at the present moment, either discarded in rivers or used for soap production, as boiler fuel or as a component of animal food supplements (Bankoviclic et al., 2014).

Likewise, throughout the world, the availability of residual oil or frying oil is significant. The discharge of oil into sewers, springs, and rivers is frequent, despite it being considered an environmental "crime". These types of oil discharges difficult the operations in wastewater treatment plants, demanding secondary and tertiary treatments for contaminants. Frying oil is a viable and advantageous alternative feedstock for biodiesel production based on environmental and economic reasons. The environmental reason relies on the fact that it prevents pollution due to the reutilization of the oil while the economic reason is due to the low cost of the oil (Felizardo et al., 2006).

Many works that focus on the economic evaluation of biodiesel production from frying oil by transesterification reaction report that it is economically viable, indicating that ultrasonic and microwave processes can be more advantageous (Araujo et al., 2010; Felizardo et al., 2006; Mohammadshirazi et al., 2014).

The fatty acid composition is not the only characteristic that makes the raw material ideal for biodiesel production. The material also must have a minimum moisture content and acidity. In some cases, processes like drying and neutralization are applied as a pre-treatment to establish the 
standard limits of moisture and acidity. Companies that produce biodiesel usually require that their suppliers of bovine tallow provide the material in ideal conditions for the production of biodiesel (Moura, 2008).

There are a few works in the literature revealing the potential different types of oil mixtures and other feedstock for biodiesel production. Issariyakul et al. (2008) investigated different mixtures of canola oil and cooking oil (100:0, 80:20, $60: 40,40: 60,20: 80,0: 100$ ) to produce biodiesel, at $50 \stackrel{\circ}{\circ}$, using $\mathrm{KOH}(1 \% \mathrm{w} / \mathrm{w})$ as catalyst, and methanol and ethanol at 6:1 (alcohol to oil molar ratio), for $2 \mathrm{~h}$ and $600 \mathrm{rpm}$. They observed that a higher methyl ester yield could be attained when canola oil was added to the feedstock mixture, using methanol as solvent. Using ethanol, a higher amount of cooking oil (at least $60 \%$ wt.\%) was required to improve ethyl methyl ester. Likewise, the application of simultaneous optimization for biodiesel production from a mixture of beef tallow and vegetable oils has also received little attention.

The application of microwave technology in the production process of biodiesel is still sparse in the scientific literature and patents. Only a few works present the advantages of applying microwavebased techniques involving rapid heating of the reaction medium and the acceleration of reactions. Among the various routes used in the synthesis of biodiesel, transesterification and esterification using heterogeneous catalysts and non-catalytic routes are the systems where higher temperatures are applied, and for which the dielectric heating would be very promising. For systems that have been operated at moderate temperatures, especially transesterification reactions via homogeneous catalysis, basic microwave technology could be useful to accelerate reaction kinetics and promote greater purity in the final product (Azcan \& Danisman, 2008).

There are studies involving the application of the microwave technology, such as the one performed by Azcan and Danisman in 2008, but none of them was done with a mixture containing the raw materials used in this work. Thus, biodiesel production from a mixture of frying oil and beef tallow, using the microwave technology, has become a prime option for the use of these residues.

Therefore, the objective of this work is to evaluate the influence of the major operational variables, such as reaction time, solvent/feed ratio, temperature, and the effect of composition of the mixtures of frying oil and bovine tallow in the transesterification reaction, using methanol as solvent and microwave technology. Specifically, the purpose of this work is to reveal what is required to mix residual oil with other feedstocks to use them in the production of fuels, focusing on economic, environmental and safety concerns.

\section{MATERIALS AND METHODS}

\subsection{Materials}

The Federal Rural University of Rio de Janeiro donated the frying oil used in this work. The oil was collected from the University's restaurant. The oil was used without any previous treatment, except for a proper filtration process, whenever required, carried out in the restaurant itself to remove any leftover solid material. Biocapital Consultory and Participations S.A (Brazil) supplied the bovine tallow.

The chemicals used were methanol (P.A., $99.8 \%$ purity), potassium hydroxide (P.A.), sulfuric acid (P.A.), n-hexane (P.A.), diethylether (P.A.), phenolphthalein (P.A.), glacial acetic acid (P.A., 99.7\% purity), and potassium iodide, from Vetec Química Fina Ltda (Rio de Janeiro, Brazil); sodium chloride (P.A.), from ProAnalysi (Isofar, Rio de Janeiro, Brazil); chloroform (P.A.), from Quimex; and soluble starch, sodium thiosulfate, and hydrochloric acid, from Analyticals Montedision (Rio de Janeiro, Brazil).

\subsection{Experimental methodology}

A pretreatment step was performed with bovine tallow samples to reduce their acidity index. Neutralization of bovine tallow was made by an acidic esterification to reduce the content of free fatty acid to less than $2 \%$. The acidic esterification was performed with $0.5 \% \mathrm{H}_{2} \mathrm{SO}_{4}$ as catalyst, an optimum concentration of 6:1 methanol/oil, at 45 ${ }^{\circ} \mathrm{C}$, for 1 hour reaction time (Wyatt et al., 2005).

Initially, the methanol and $\mathrm{KOH}$ used as catalysts were mixed to prepare the alkoxide solution. The solvent/feed ratio (S/F) used in the experiments was established. The reaction was 
Table 1. $2^{4}$ Full Factorial Design for biodiesel production with microwave technology.

\begin{tabular}{cccc}
\hline Independent variables & \multicolumn{3}{c}{ Levels } \\
\cline { 2 - 4 } & -1 & 0 & 1 \\
\hline Catalyst concentration $(\mathbf{K O H})-\mathbf{X}_{\mathbf{1}}$ & 0.5 & 1.5 & 1 \\
Mixture $-\mathbf{X}_{\mathbf{2}}$ & $30 / 70^{*}$ & $50 / 50^{* *}$ & $70 / 30^{* * *}$ \\
Reaction Time $(\mathbf{s})-\mathbf{X}_{\mathbf{3}}$ & 10 & 22 & 35 \\
S/F ratio $-\mathbf{X}_{\mathbf{4}}$ & $3: 1$ & $6: 1$ & $9: 1$ \\
\hline
\end{tabular}

*30/70 - Mixtures: $30 \%$ of frying oil $+70 \%$ bovine tallow

$* * 50 / 50$ - Mixtures: $50 \%$ of frying oil $+50 \%$ bovine tallow

$* * * 70 / 30$ - Mixtures: $70 \%$ of frying oil $+30 \%$ bovine tallow

done in a flat-bottomed flask $(1000 \mathrm{~mL})$ inside a domestic microwave oven at maximal power, at pre-determined times $(10,22$, and 35 seconds). After reaching the reaction time, the products obtained were separated and purified. The separation was performed using a centrifuge (New Technique, Model NT 820), for $15 \mathrm{~min}$ at $3000 \mathrm{rpm}$, and a separation funnel. Glycerol was removed, and the obtained biodiesel was washed with a $5 \%$ $(w / w)$ aqueous solution of sodium sulphate, until the washing solution became clear. After the washing process, biodiesel was oven dried, for 1 hour at $105{ }^{\circ} \mathrm{C}$, and then filtered with anhydrous sodium sulfate. The experimental procedures were done in the Biofuels and Applied Thermodynamic Laboratory at the Chemical Engineering Department of the Federal Rural University of Rio de Janeiro.

\subsection{Experimental design}

The response surface methodology (RSM) was used to determine the optimum operating ranges of each variable. The experiments were done according to a $2^{4}$ full factorial design (FFD) with 4 center points (CP), comprising 20 experimental runs. The influence on the biodiesel yield (by weight and ester content) of the following independent variables was investigated: S/F ratio (methanol/oil molar ratio), different percentages of oils in the mixture, the amount of $\mathrm{KOH}$, and reaction time. The effect of variables and their errors were calculated for a $95 \%$ confidence level.

The values adopted for the independent variables are presented in Table 1 . They were chosen according to the best operational results found in similar works using the same raw materials, bovine tallow and frying oil (Moura, 2010).
For each level combination in the planning matrix, the regression coefficients were also analyzed for each parameter, and the estimations were done with levels higher than $95 \%$ and $92 \%$ ( $p$ $<0.05$ and $p<0.08$ ) (Rodrigues \& lemma, 2005).

\subsection{Chromatographic analysis}

Identification and quantification of fatty acids in frying oil and bovine tallow samples were performed by gas chromatography, after the derivatization step of the oil to avoid clogging of the column (Felizardo et al., 2006). An INTECROM G 8000 equipped with a CP-CIL 88 FAME column (100 m length $\times 0.25 \mathrm{~mm} \times 0.20 \mu \mathrm{m}$ thick film) was used with a FID detector.

The saponification reactions were performed in test tubes with screw caps. For each 200 to $500 \mathrm{mg}$ of the lipid sample, $3 \mathrm{~mL}$ of $0.5 \mathrm{~mol}^{-\mathrm{L}^{-1}}$ methanolic sodium hydroxide solution were added, and the samples were placed in a water bath (at boiling temperature for $30 \mathrm{~min}$ ). Afterwards, the test tubes were cooled and $5 \mathrm{~mL}$ of the methylation reagent were added. The mixtures were heated at boiling temperature under reflux for $5 \mathrm{~min}$. After cooling, $8 \mathrm{~mL}$ of sodium chloride saturated solution were added. The methyl esters migrated to the top of the solution and were solubilized by adding $2 \mathrm{~mL}$ of $n$-hexane.

The esters obtained were injected into a gas chromatograph. The chromatographic operating conditions were: $1 \mu \mathrm{L}$ injection volume, $140{ }^{\circ} \mathrm{C}$ initial temperature, $4{ }^{\circ} \mathrm{C} / \mathrm{min}$ heating rate, $240{ }^{\circ} \mathrm{C}$ final temperature, $250{ }^{\circ} \mathrm{C}$ injector temperature, $280^{\circ} \mathrm{C}$ detector temperature, $5 \mathrm{~min}$ initial time, 40 min total time, $70 \mathrm{kPa}$ column pressure, 1:50 split, with $1 \mathrm{~mL} / \mathrm{min}$ helium carrier gas flow rate, 300 $\mathrm{mL} / \mathrm{min}$ synthetic air flow rate, $30 \mathrm{~mL} / \mathrm{min}$ nitrogen flow rate. Biodiesel was also analyzed by gas 
Table 2. Oils, fats, and derivatives analyses.

\begin{tabular}{lc}
\hline \multicolumn{1}{c}{ Properties } & Methods \\
\hline Acid $(\mathrm{mg} \mathrm{KOH} / \mathrm{g})$ & AOCS Bc 3d-63 \\
Saponification $(\mathrm{mg} \mathrm{KOH} / \mathrm{g})$ & SMAOFD 2.202 \\
Refractive index at $25^{\circ} \mathrm{C}$ & AOCS Cc 7-25 \\
lodine $\left(\mathrm{g} \mathrm{I}_{2} / 100 \mathrm{~g}\right)$ & AOCS Cd 1c-85 \\
Moisture $(\%)$ & AOCS Bc 2-49 \\
Viscosity at $40{ }^{\circ} \mathrm{C}\left(\mathrm{mm}^{2} / \mathrm{s}\right)$ & ASTM D 445 \\
Density $\left(\mathrm{kg} / \mathrm{m}^{3}\right)$ & ASTM D 4052 \\
\hline
\end{tabular}

Table 3. Physicochemical properties of frying oil, bovine tallow, and their mixtures.

\begin{tabular}{lcccccc}
\hline \multicolumn{1}{c}{ Physicochemical Properties } & Frying Oil & $\begin{array}{c}\text { Bovine } \\
\text { tallow }\end{array}$ & $\mathbf{7 0 / 3 0}$ & $\mathbf{5 0 / 5 0}$ & $\mathbf{3 0 / 7 0}$ & $\begin{array}{c}\text { ANP } \\
\text { values }\end{array}$ \\
\hline Acidity index $(\mathrm{mg} \mathrm{KOH} / \mathrm{g})$ & 0.54 & 1.74 & 0.55 & 1.45 & 1.67 & 0.50 \\
lodine index $\left(\mathrm{g} \mathrm{I}_{2} / \mathrm{100 \textrm {g } )}\right.$ & 180.81 & 63.57 & 167.3 & 128.60 & 96.45 & 120 \\
Saponification number $(\mathrm{mg} \mathrm{KOH} / \mathrm{g})$ & 197.90 & 197.90 & 191.40 & 192.10 & 192.40 & - \\
Moisture $(\%)$ & 0.19 & 0.18 & 0.19 & 0.18 & 0.18 & $<0.2 \%$ \\
Density $\left(\mathrm{kg} / \mathrm{m}^{3}\right)$ & 909.68 & 902.31 & 905.52 & 906.04 & 906.29 & $850-900$ \\
Viscosity at $40^{\circ} \mathrm{C}\left(\mathrm{mm}^{2} / \mathrm{s}\right)$ & 36.41 & 46.99 & 42.16 & 43.09 & 46.61 & $3-6$ \\
Refractive Index at $25^{\circ} \mathrm{C}$ & 1.48 & 1.46 & 1.45 & 1.46 & 1.47 & - \\
\hline
\end{tabular}

chromatography (GC), but it was necessary to filter each sample to retain particles that could damage the equipment.

\subsection{Sample analysis}

The analyses of frying oil and bovine tallow samples followed the international regulations of Standard Methods for the Analysis of oils, fats, and derivatives (SMAOFD, 2016), the American Oil Chemists Society Official and Tentative Methods (Sulistyo et al., 2008), and the American Society for Testing and Materials (ASTM, 2016). All the specification analyses of the raw materials are presented in Table 2 . The analyses were done in triplicate.

\section{RESULTS AND DISCUSSION}

\subsection{Physicochemical analysis of the oils and mixtures (FOT)}

A physicochemical characterization of the oils and their mixtures was performed according to the acidity value, iodine value, saponification number, moisture, density, kinematic viscosity, and refractive index, after a pretreatment step, whenever necessary. The analyses were done in triplicate, and Table 3 presents the average results of the physicochemical properties. Table 3 also presents the ANP values for each quality parameter for biodiesel. In particular, it must be pointed out that determination of the saponification number and refractive index is not mandatory by the National Regulatory Agency of Petroleum, Gas and Biofuels (ANP).

Reports in the literature (Fangrui et al., 1999; Fukuda et al., 2001; Ma \& Hanna, 1999) show that the ideal conditions for biodiesel production, considering acidity, are values below $2.0 \mathrm{mg}$ $\mathrm{KOH} / \mathrm{g}$. Table 3 shows $8.46 \mathrm{mg} \mathrm{KOH} / \mathrm{g}$ for bovine tallow prior to the pre-treatment, thus, it was neutralized, reaching $1.74 \mathrm{mg} \mathrm{KOH} / \mathrm{g}$.

It could be observed that acidity values were below $2 \mathrm{mgKOH} / \mathrm{g}$, and moisture contents for all samples were according to the limits established by ANP (2016).

The values for kinematic viscosity are in the range of 36 and $47 \mathrm{~mm}^{2} / \mathrm{s}$, which are not in agreement with the ranges specified for these mixtures according to ANP. The viscosity increases with the length of the triglycerides and fatty acid carbon chain, and decreases when the unsaturation degree increases (Moretto \& Fett, 1998). 
Table 4. Composition of fatty acids found in frying oil, bovine tallow, and mixtures.

\begin{tabular}{|c|c|c|c|c|c|c|c|c|}
\hline \multicolumn{3}{|c|}{ Fatty Acids } & \multicolumn{6}{|c|}{ Molar Mass and Compositions } \\
\hline Abbreviation & IUPAC Name & Name & $\begin{array}{l}\text { Molar } \\
\text { Mass }\end{array}$ & $\begin{array}{l}\text { Frying Oil } \\
\text { (\%) }\end{array}$ & $\begin{array}{c}\text { Bovine } \\
\text { tallow (\%) }\end{array}$ & $\begin{array}{c}70 / 30 \\
(\%)\end{array}$ & $\begin{array}{c}50 / 50 \\
(\%)\end{array}$ & $\begin{array}{c}30 / 70 \\
(\%)\end{array}$ \\
\hline C $14: 0$ & Tetradecanoic acid & Myristic acid & 242.39 & 2.92 & 2.27 & 0.63 & 1.20 & 1.48 \\
\hline C $16: 0$ & Hexadecanoic acid & Palmitic acid & 270.44 & 18.23 & 23.71 & 14.25 & 17.08 & 18.84 \\
\hline C $18: 0$ & Octadecenoic acid & Stearic acid & 298.50 & 1.66 & 16.25 & 7.15 & - & 11.89 \\
\hline C 18:1 & 9-octadecenoic acid & Oleic acid & 296.48 & 19.49 & 34.96 & 27.37 & 10.31 & 30.55 \\
\hline C $18: 2$ & $\begin{array}{l}9,12- \\
\text { octadecadienoic acid }\end{array}$ & Linoleic acid & 294.47 & 49.65 & 12.54 & 47.99 & 31.69 & 29.56 \\
\hline C $18: 3$ & $\begin{array}{l}\text { Octadecatrienoic } \\
\text { acid }\end{array}$ & Linolenic acid & 292.45 & 6.52 & - & 4.66 & 0.29 & 2.49 \\
\hline C $20: 0$ & Eicosanoic acid & $\begin{array}{l}\text { Arachidonic } \\
\text { acid }\end{array}$ & 326.55 & - & - & 0.31 & 32.30 & 2.84 \\
\hline
\end{tabular}

The saponification number (SN) is a characteristic of vegetable oils, being inversely proportional to the average molecular weight of the fatty acids present in the triglycerides. This means that when the size of the fatty acid chain increases, oil saponification rate decreases (Kucek et al., 2007; Moura, 2008; Wyatt et al., 2005). The SN found for oils and mixtures thereof are within the range of 192 to $198 \mathrm{mg} \mathrm{KOH} / \mathrm{g}$.

The iodine index of the oils and mixtures is between 63 and $181 \mathrm{~g} \mathrm{I}_{2} / 100 \mathrm{~g}$ (McCormick et al., 2001). This analysis consists of an empiric method to measure the unsaturation degree present in the biofuel. According to Pereira (2007), when the iodine index increases, the unsaturation degree also increases; this is a sign that the vegetable oil and/or biofuel has a great tendency to oxidize. In the literature, it is possible to find iodine indexes for frying oil ranging between 69 and $143 \mathrm{~g} \mathrm{I}_{2} / 100 \mathrm{~g}$ (Demirbas, 2002; Silva et al., 2010).

\subsection{Characterization of the frying oil and bovine tallow (FOT) mixture}

\subsubsection{Chemical composition}

The mixtures were subjected to an alkaline methanolysis, and the obtained esters were analyzed by gas chromatography. The contents of fatty acids present in frying oil, bovine tallow, and mixtures are shown in Table 4. The values of the chemical composition in terms of fatty acids for frying oil and bovine tallow are in agreement with data available in literature for the average composition of the oils (Moura, 2010; 2008).

Based on the values of Table 4, it was possible to calculate the average molecular weight of the frying oil $(820.13 \mathrm{~g} / \mathrm{mol})$; bovine tallow $(840.59$ $\mathrm{g} / \mathrm{mol}) ; 70 / 30$ mixture $(827.00 \mathrm{~g} / \mathrm{mol}) ; 50 / 50$ mixture $(821.57 \mathrm{~g} / \mathrm{mol}) ;$ and $30 / 70$ mixture $(837.14$ $\mathrm{g} / \mathrm{mol}$ ). It could be also observed that the chemical composition of the oils and the mixtures were based mainly on palmitic, oleic, and linoleic fatty acids.

\subsection{Transesterification reaction}

The results concerning the biodiesel production were analyzed in terms of biodiesel yield ( $\% R)$ and ester content $(\% \mathrm{E})$, as shown in Table 5 . The biodiesel yield by weight (\% R) was calculated with Equation 1:

$$
\% R=\frac{m_{\text {biod }} \cdot M M_{\text {oil }}}{m_{\text {oil }} \cdot M M_{\text {biod }}} \cdot 100
$$

Where $m_{\text {biod }}$ is the purified biodiesel mass, $M_{\text {oil }}$ is the average molar mass of the oil mixture, $m_{\text {oil }}$ is the mass of the oil mixture, and $\mathrm{MM}_{\text {biod }}$ is the average molar mass of biodiesel.

The yield of ester (\% E), or the ester content, produced with frying oil and bovine tallow, was named as BTFM, and was defined as the sum of the 
Table 5. Results of biodiesel production according to the $2^{4}$ factorial design.

\begin{tabular}{ccccccccccc}
\hline & \multicolumn{3}{c}{ Coded variables } & \multicolumn{3}{c}{ Independent variables } & \multicolumn{2}{c}{ Dependent variables (Yields) } \\
\hline Assay & $\mathbf{X}_{\mathbf{1}}$ & $\mathbf{X}_{\mathbf{2}}$ & $\mathbf{X}_{\mathbf{3}}$ & $\mathbf{X}_{\mathbf{4}}$ & $\mathbf{X}_{\mathbf{1}}$ & $\mathbf{X}_{\mathbf{2}}$ & $\mathbf{X}_{\mathbf{3}}$ & $\mathbf{X}_{\mathbf{4}}$ & ${ }^{*} \mathbf{R}(\%)$ & $*$ E (\%) \\
1 & -1 & -1 & -1 & -1 & 0.5 & $30 / 70$ & 10 & $3: 1$ & 81.17 & 97.33 \\
2 & -1 & -1 & -1 & 1 & 0.5 & $30 / 70$ & 10 & $9: 1$ & 81.04 & 99.13 \\
3 & -1 & -1 & 1 & -1 & 0.5 & $30 / 70$ & 35 & $3: 1$ & 70.84 & 98.75 \\
4 & -1 & -1 & 1 & 1 & 0.5 & $30 / 70$ & 35 & $9: 1$ & 65.98 & 99.06 \\
5 & -1 & 1 & -1 & -1 & 0.5 & $70 / 30$ & 10 & $3: 1$ & 70.20 & 99.19 \\
6 & -1 & 1 & -1 & 1 & 0.5 & $70 / 30$ & 10 & $9: 1$ & 75.95 & 99.33 \\
7 & -1 & 1 & 1 & -1 & 0.5 & $70 / 30$ & 35 & $3: 1$ & 88.57 & 99.15 \\
8 & -1 & 1 & 1 & 1 & 0.5 & $70 / 30$ & 35 & $9: 1$ & 75.78 & 99.43 \\
9 & 1 & -1 & -1 & -1 & 1.5 & $30 / 70$ & 10 & $3: 1$ & 51.14 & 99.09 \\
10 & 1 & -1 & -1 & 1 & 1.5 & $30 / 70$ & 10 & $9: 1$ & 84.90 & 99.18 \\
11 & 1 & -1 & 1 & -1 & 1.5 & $30 / 70$ & 35 & $3: 1$ & 62.56 & 99.11 \\
12 & 1 & -1 & 1 & 1 & 1.5 & $30 / 70$ & 35 & $9: 1$ & 59.17 & 99.11 \\
13 & 1 & 1 & -1 & -1 & 1.5 & $70 / 30$ & 10 & $3: 1$ & 68.23 & 99.11 \\
14 & 1 & 1 & -1 & 1 & 1.5 & $70 / 30$ & 10 & $9: 1$ & 88.87 & 99.42 \\
15 & 1 & 1 & 1 & -1 & 1.5 & $70 / 30$ & 35 & $3: 1$ & 60.88 & 99.26 \\
16 & 1 & 1 & 1 & 1 & 1.5 & $70 / 30$ & 35 & $9: 1$ & 85.00 & 98.42 \\
17 & 0 & 0 & 0 & 0 & 1 & $50 / 50$ & 22.5 & $6: 1$ & 80.30 & 99.14 \\
18 & 0 & 0 & 0 & 0 & 1 & $50 / 50$ & 22.5 & $6: 1$ & 78.90 & 99.13 \\
19 & 0 & 0 & 0 & 0 & 1 & $50 / 50$ & 22.5 & $6: 1$ & 75.63 & 99.10 \\
20 & 0 & 0 & 0 & 0 & 1 & $50 / 50$ & 22.5 & $6: 1$ & 78.56 & 99.04 \\
\hline
\end{tabular}

$* \mathrm{R}=$ Biodiesel yield mass, $* * \mathrm{E}=$ Ester content

Table 6. Effects of factors and standard errors corresponding to the mass yield in BFTM

\begin{tabular}{lccccc}
\hline \multicolumn{1}{c}{ Factors } & Effects & $\begin{array}{c}\text { Regression } \\
\text { Coefficients }\end{array}$ & Standard Error & tcal* & p-Value** \\
\hline Mean & 74.284 & 74.284 & 0.439 & 169.326 & $<0.0001$ \\
& & & & & \\
$\mathrm{X}_{1}: \mathrm{KOH}$ & -6.098 & -3.049 & 0.981 & -6.216 & 0.008 \\
$\mathrm{X}_{2}:$ Mixture & 7.335 & 3.668 & 0.981 & 7.477 & 0.005 \\
$\mathrm{X}_{3}:$ Time & -4.090 & -2.045 & 0.981 & -4.169 & 0.025 \\
$\mathrm{X}_{4}:$ molar ratio & 7.888 & 3.944 & 0.981 & 8.041 & 0.004 \\
Interactions & & & & & \\
$\mathrm{X}_{1} \mathrm{X}_{2}$ & 4.218 & 2.109 & 0.981 & 4.299 & 0.023 \\
$\mathrm{X}_{1} \mathrm{X}_{3}$ & -2.543 & -1.271 & 0.981 & -2.592 & 0.081 \\
$\mathrm{X}_{1} \mathrm{X}_{4}$ & 11.145 & 5.573 & 0.981 & 11.361 & 0.001 \\
$\mathrm{X}_{2} \mathrm{X}_{3}$ & 5.835 & 2.918 & 0.981 & 5.948 & 0.010 \\
$\mathrm{X}_{2} \mathrm{X}_{4}$ & 1.543 & 0.771 & 0.981 & 1.572 & 0.214 \\
$\mathrm{X}_{3} \mathrm{X}_{4}$ & -7.368 & -3.684 & 0.981 & -7.510 & 0.005 \\
\hline $\mathrm{t}_{\mathrm{t} \text { statistical test, }}^{* *}$ significance probability of the t-test & & & \\
\hline
\end{tabular}

percentage of all ethyl esters identified and quantified by chromatographic analysis.

\subsubsection{Yield analysis}

The assays were based on the variance analysis (ANOVA), used to obtain some statistical parameters, such as the mean and the sum of standard errors (SS).
Interactions between variables and standard errors were calculated to evaluate the effects of the independent variables on the total yield of the biodiesel from frying oil and bovine tallow mixtures (BFTM). Statistical values (as main effects), regression coefficients, interactions, and standard errors are presented in Table 6.

Table 6 indicates that factors $X_{2}$ and $X_{4}$ and 
Table 7. Analysis of variance (ANOVA) for model regression.

\begin{tabular}{|c|c|c|c|c|c|}
\hline $\begin{array}{l}\text { Source of } \\
\text { variation }\end{array}$ & SS & $\mathrm{DF}^{*}$ & MS** & F-Calc & F-Tab \\
\hline Regression & 1636.367 & 8.00 & 204.546 & 4.90 & 2.95 \\
\hline residual & 458.765 & 11.00 & 41.706 & & \\
\hline Lack of fit & 447.217 & 6 & & & \\
\hline Pure error & 11.547 & 3 & & & \\
\hline TOTAL SS & 2095.132 & 19.00 & & & \\
\hline $\mathrm{R}^{2}$ & 0.781 & & & & \\
\hline
\end{tabular}

interactions $\mathrm{X}_{1} \mathrm{X}_{4}$ and $\mathrm{X}_{3} \mathrm{X}_{4}$ are statistically significant. Therefore, factors $X_{1}$ and $X_{3}$ and interactions $\mathrm{X}_{1} \mathrm{X}_{2}, \mathrm{X}_{1} \mathrm{X}_{3}, \mathrm{X}_{2} \mathrm{X}_{3}$, and $\mathrm{X}_{2} \mathrm{X}_{4}$ exceeded the $P$-value (probability of error value), indicating that they are not statistically significant. The variables with positive values indicate that an increase in their levels provide a higher total yield, and the negative ones indicate an opposite effect.

It is important to note that the interaction between $\mathrm{KOH}$ and molar ratio is the one that affected most the yield in biodiesel production. This influence is positive, confirming that the yield increases when the interaction values also increase. This can be explained due to the easy phase separation between biodiesel and glycerin, and due to the excess S/F molar ratio that was higher in amount than the stoichiometric factor, therefore, shifting the equilibrium in the direction of the products.

The result of analysis of variance (ANOVA), which was carried out to determine the significance and the fitting of the model, as well as the effect of significant individual terms and their interaction on the chosen responses, are presented in Table 7. The P-value is used as a tool to check the significance of each regression coefficient, which also indicates the interaction effect of each cross product. The smaller the P-value is, the higher the significance of the corresponding coefficient will be. The results are in agreement

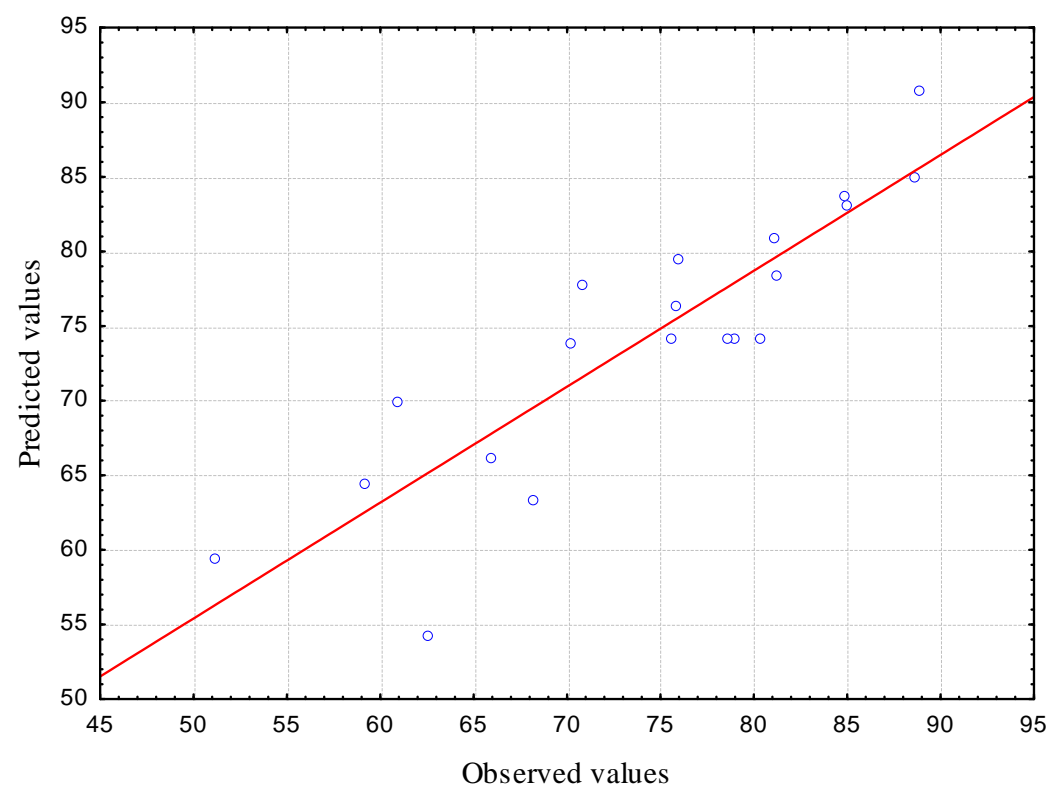

Figure 1. Distribution of residuals: predicted versus observed values of BFTM production. 


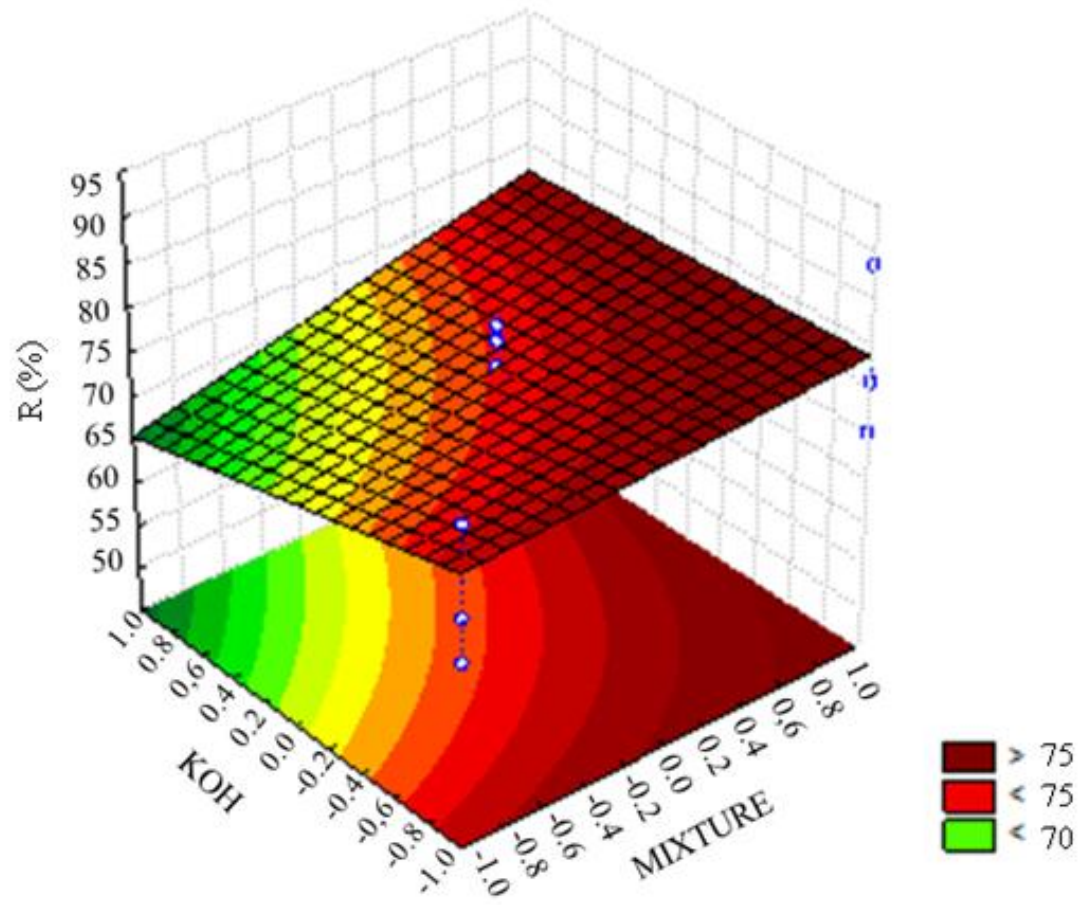

Figure 2. Surface plot of the yield as a function of the interaction of catalyst concentration and type of mixture.

with other works already published in the literature (Charoenchaitrakool \& Thienmethangkoon, 2011; Lee et al., 2011; Shin et al., 2012) with respect to the significant variables.

The F-test indicated that the regression analysis was significant, since the Fcal value (4.90) was higher than Ftab one (2.95), and the model does not need any adjustment. The correlation coefficient $\left(R^{2}\right)$ provides a measure of the proportion of variance explained by the regression equation to responses variation (Costa Neto et al., 2000). In general, $R^{2}$ is expressed in percentage, and $78 \%$ was the $R^{2}$ value of this model.

The residue distribution (predicted values versus observed ones) is shown in Figure 1. One can notice that the average values are close to the red line and the deviations between them are distributed normally; positive and negative deviations are in the same proportion, with no tendentious behavior.

The response surface was estimated with Equation 2, where $X_{1}, X_{2}, X_{3}$, and $X_{4}$ are the variables describing factors $\beta_{0}$ (intersection point), $\beta_{1}, \beta_{2}, \beta_{3}$, and $\beta_{4}$ (referring to the linear effects) and the interaction effects between the variables are the regression coefficients obtained by the method applying the least squares methodology. Equation 2 is the model that describes the response surface for the BFTM biodiesel efficiency.

$$
\begin{aligned}
& R=74.284-3.049 \cdot X_{1}+3.668 \cdot X_{2}-2.045 \cdot X_{3}+ \\
& +3.944 \cdot X_{4}+2.109 \cdot X_{1} X_{2}+5.573 \cdot X_{1} X_{4}+ \\
& +2.918 \cdot X_{2} X_{3}-3.684 \cdot X_{3} X_{4}
\end{aligned}
$$

A similar and acceptable accuracy of the model $\left(R^{2}=0.85\right)$ was also found by another work using only frying oil as raw material, $65{ }^{\circ} \mathrm{C}$ of temperature reaction, $45 \mathrm{~min}$ of time, a methanol:oil molar ratio of 9 , and using $\mathrm{NaOH}$ concentration of $0.72 \mathrm{w} / \mathrm{w}$, obtaining $92.05 \%$ ester yield (Atapour et al., 2014).

The response surface defines the most appropriate condition that can maximize the yield of BFTM. Figure 2 shows the variation of the yield (\%) as a function of catalyst concentration and type of mixture. A mixture of $70 / 30$ and $0.5 \%$ of catalyst led to yields with mass higher than $85 \%$.

The variation of the yield (\%) as a function of time and type of mixture is shown in Figure 3. Yields higher than $77 \%$ by weight were also obtained with a mixture of 70/30 in 35 seconds of reaction. 


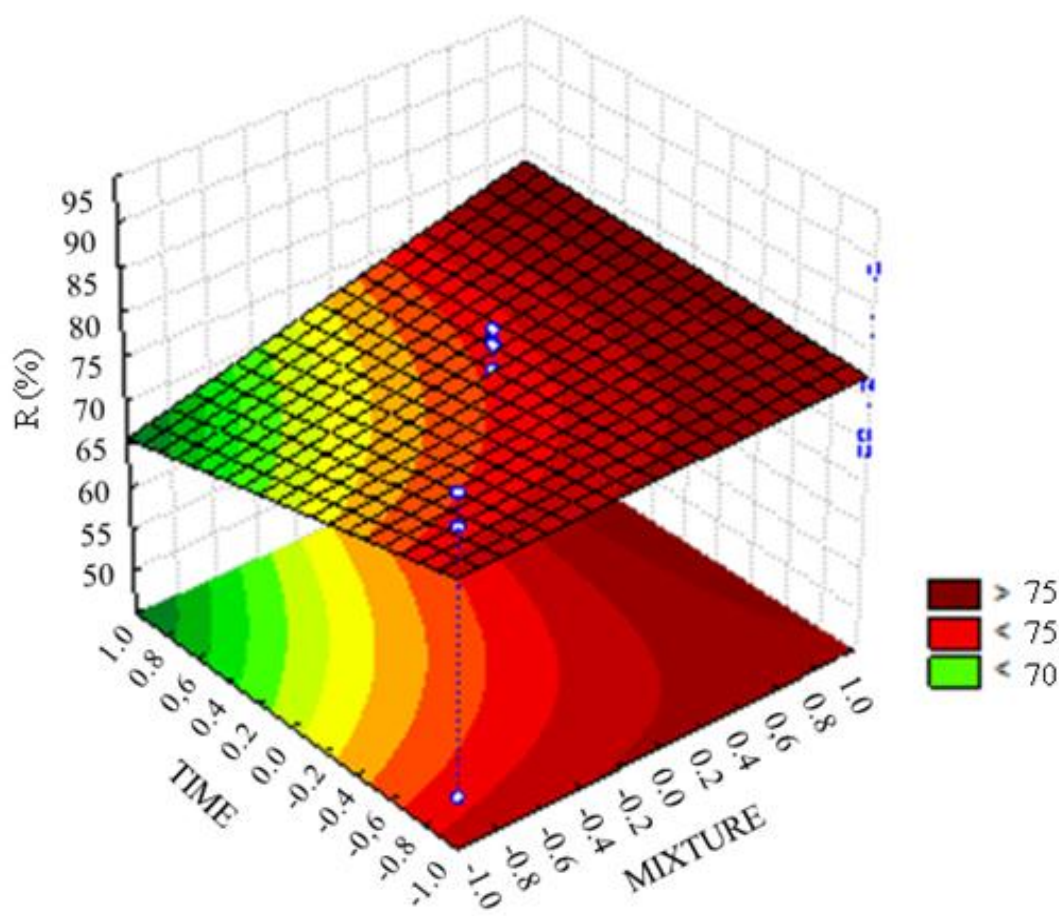

Figure 3. Surface plot of the yield as a function of the interaction of time and type of mixture.

The variation of the biodiesel yield (\%) as a function of the alcohol:oil molar ratio and type of mixture is shown in Figure 4. Again, yields higher than $81 \%$ were attained using a mixture of $70 / 30$ $\%$ and an alcohol:oil molar ratio of 9:1.

\subsubsection{Ester conversion analysis}

Table 8 shows the effects of the variables $X_{1}, X_{2}$, $X_{3}$, and $X_{4}$ and of interactions $X_{1} X_{2}, X_{1} X_{3}, X_{1} X_{4}, X_{2} X_{3}$, $X_{2} X_{4}$, and $X_{3} X_{4}$, as previously presented for the yield in mass, but now as a function of ester conversion. The data presented in Table 8 are statistically significant, with type of mixture and molar ratio as the main effects observed. The variables $X_{1}$ and $X_{3}$ exceeded the $p$-value, indicating that they are not statistically significant. The interaction between the content of $\mathrm{KOH}$ and the mixture is the one that produces a more significant effect on responses of the ester content.

Table 8. Effects of the factors and standard errors corresponding to the yield for the ester content BFTM.

\begin{tabular}{|c|c|c|c|c|c|}
\hline Factors & Effects & $\begin{array}{l}\text { Regression } \\
\text { coefficients }\end{array}$ & $\begin{array}{c}\text { Standard } \\
\text { Error }\end{array}$ & & P-Value \\
\hline Mean & 99.024 & 99.024 & 0.010 & 9841.084 & $<0.0001$ \\
\hline \multicolumn{6}{|l|}{ Main Effects } \\
\hline $\mathrm{X}_{1}: \mathrm{KOH}$ & 0.166 & 0.083 & 0.022 & 7.389 & 0.005 \\
\hline $\mathrm{X}_{2}$ :Mixture & 0.319 & 0.159 & 0.022 & 14.167 & 0.001 \\
\hline $\mathrm{X}_{3}$ :Time & 0.064 & 0.159 & 0.022 & 2.833 & 0.066 \\
\hline $\mathrm{X}_{4}$ :molar ratio & 0.261 & 0.131 & 0.022 & 11.611 & 0.001 \\
\hline \multicolumn{6}{|l|}{ Interactions } \\
\hline $\mathrm{X}_{1} \mathrm{X}_{2}$ & -0.389 & -0.194 & 0.022 & -17.278 & $<0.0001$ \\
\hline$X_{1} X_{3}$ & -0.289 & -0.144 & 0.022 & -12.833 & 0.001 \\
\hline$X_{1} X_{4}$ & -0.371 & -0.186 & 0.022 & -16.500 & $<0.0001$ \\
\hline$x_{2} x_{3}$ & -0.261 & -0.131 & 0.022 & -11.611 & 0.001 \\
\hline$X_{2} X_{4}$ & -0.289 & -0.144 & 0.022 & -12.833 & 0.001 \\
\hline$X_{3} X_{4}$ & -0.324 & -0.162 & 0.022 & -14.389 & 0.001 \\
\hline
\end{tabular}




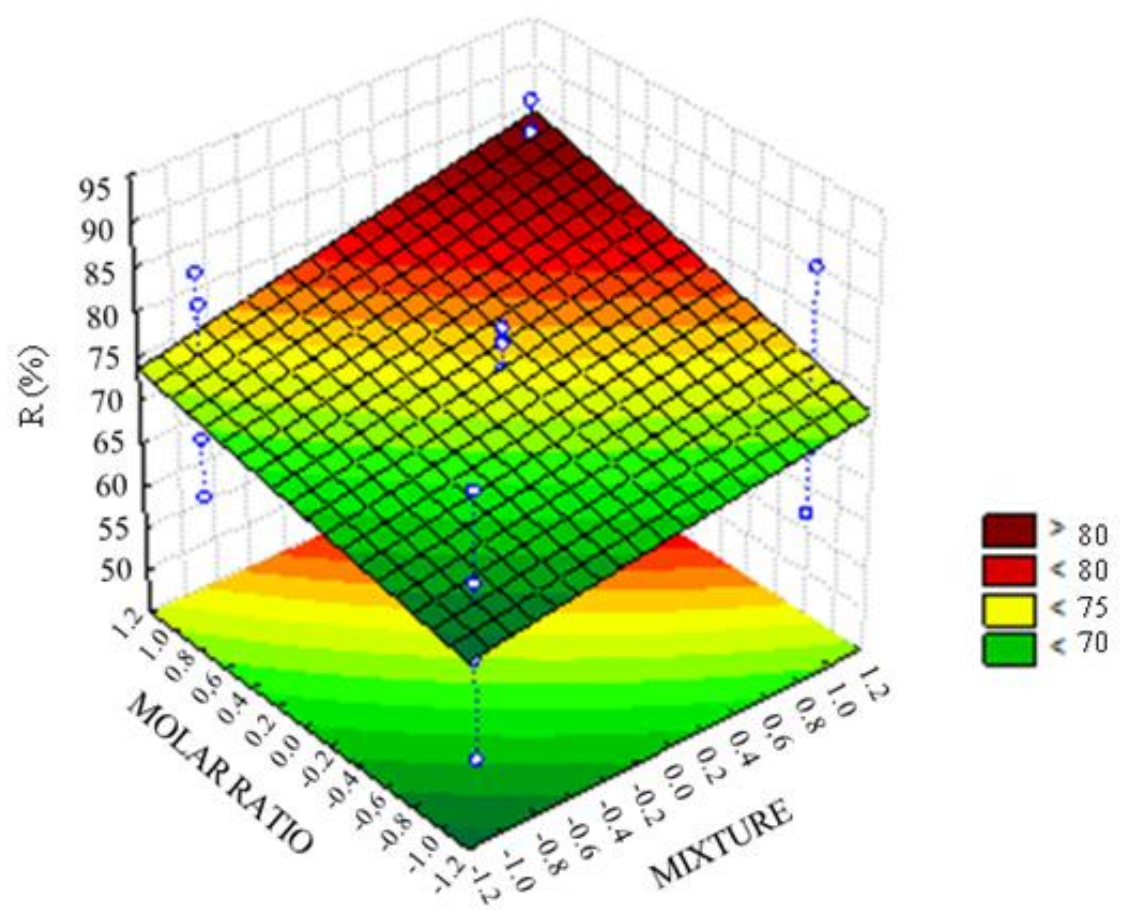

Figure 4. Surface plot of the yield as a function of the interactions of alcohol:oil molar ratio and type of mixture.

The variation of the experimental results was statistically verified by the performance of the residue analysis. The analysis of variance for this model (Table 9), through the F-test, indicated that the regression is significant since the value of $F_{\text {cal }}$ (6.581) is higher than the $F_{\text {tab }}(3.02)$, as shown for the yield evaluation.

The correlation coefficient for the ester content was $0.855(85 \%)$, not requiring any adjustment to the model. The distribution of the residues is presented in Figure 5, where one can see that observed and predicted values are well distributed.

Equation 3 is the model that describes the response surface for the esters content of BFTM.

$E=99.024+0.083 \cdot X_{1}+0.159 \cdot X_{2}+$

$+0.131 \cdot X_{4}-0.194 \cdot X_{1} X_{2}-0.144 \cdot X_{1} X_{3}-$

$-0.186 \cdot X_{1} X_{4}-0.131 \cdot X_{2} X_{3}-$

$-0.144 \cdot X_{2} X_{4}-0.162 \cdot X_{3} X_{4}$

Figures 6 and 7 show higher ester contents in the biodiesel produced, $99.3 \%$ and $99.2 \%$,

Table 9. Analysis of variance (ANOVA) for model regression.

\begin{tabular}{lcclll}
\hline \multicolumn{1}{c}{ Effect } & SS & DF* & MS** & F-Calc & F-Tab \\
\hline Regression (R) & 3.352 & 9.00 & 0.372 & 6.581 & 3.020 \\
residual $(r)$ & 0.566 & 10.00 & 0.057 & & \\
Lack of fit & 0.560 & 5.00 & & & \\
Pure error & 0.006 & 3 & & & \\
TOTAL & 3.918 & 19 & & & \\
$\mathrm{R}^{2}$ & 0.855 & & & & \\
\hline
\end{tabular}

* degree of freedom, $* *$ mean square 


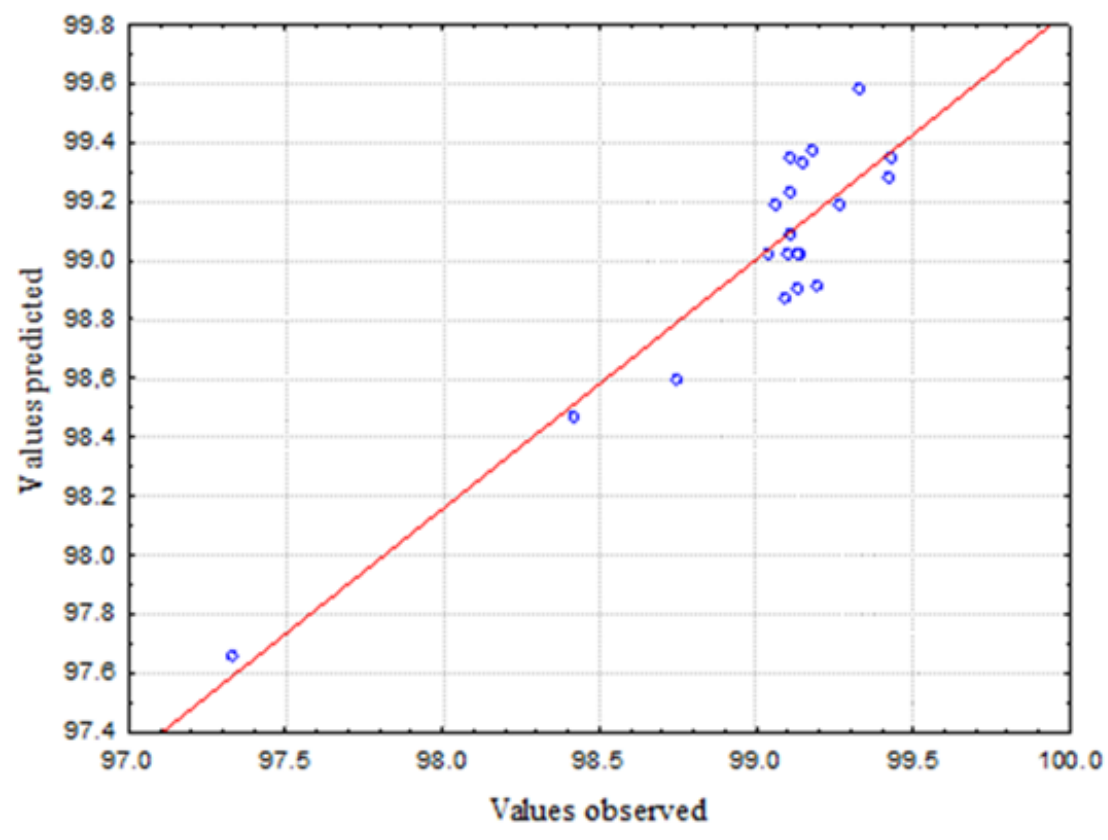

Figure 5. Distribution of residues predicted as a function of observed values for esters content of BFTM biodiesel.

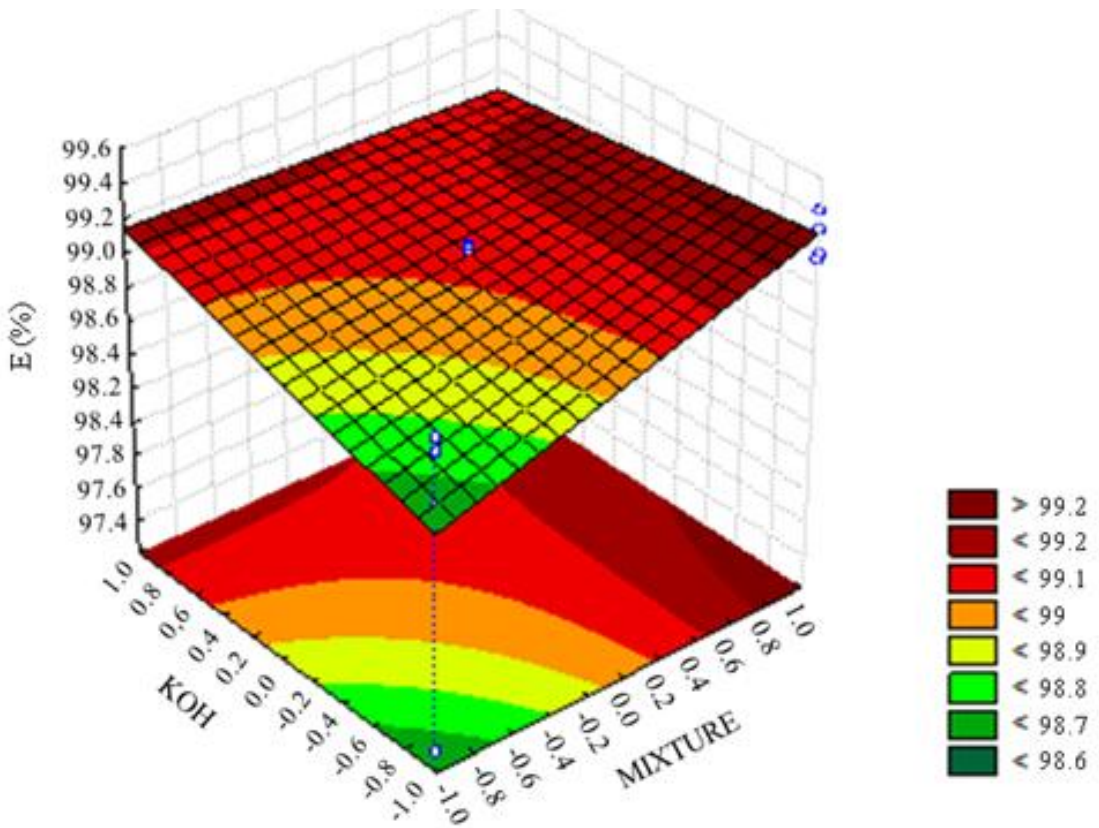

Figure 6. Surface plot of $E(\%)$ as a function of the interactions of catalyst concentration and type of mixture.

respectively, using a lower catalyst concentration and a higher reaction time. The best type of mixture applied was the one with $70 \%$ of frying oil and $30 \%$ of tallow. Another conclusion based on the response surface methodology is that the higher ester content (99.1\%) was obtained when a higher alcohol:oil molar ratio and a mixture of 70/30 were applied (Figure 8).
Mendonça et al. (2011) adopted the same strategy for optimization using only beef tallow as raw material for the biodiesel production. Mixture percentage was not an independent variable in the design factorial. The best operational conditions were 7.5:1 of alcohol:oil molar ratio, using methanol as solvent, $1.5 \%$ of catalyst, 20 min of reaction time and $50{ }^{\circ} \mathrm{C}$ to achieve a conversion 


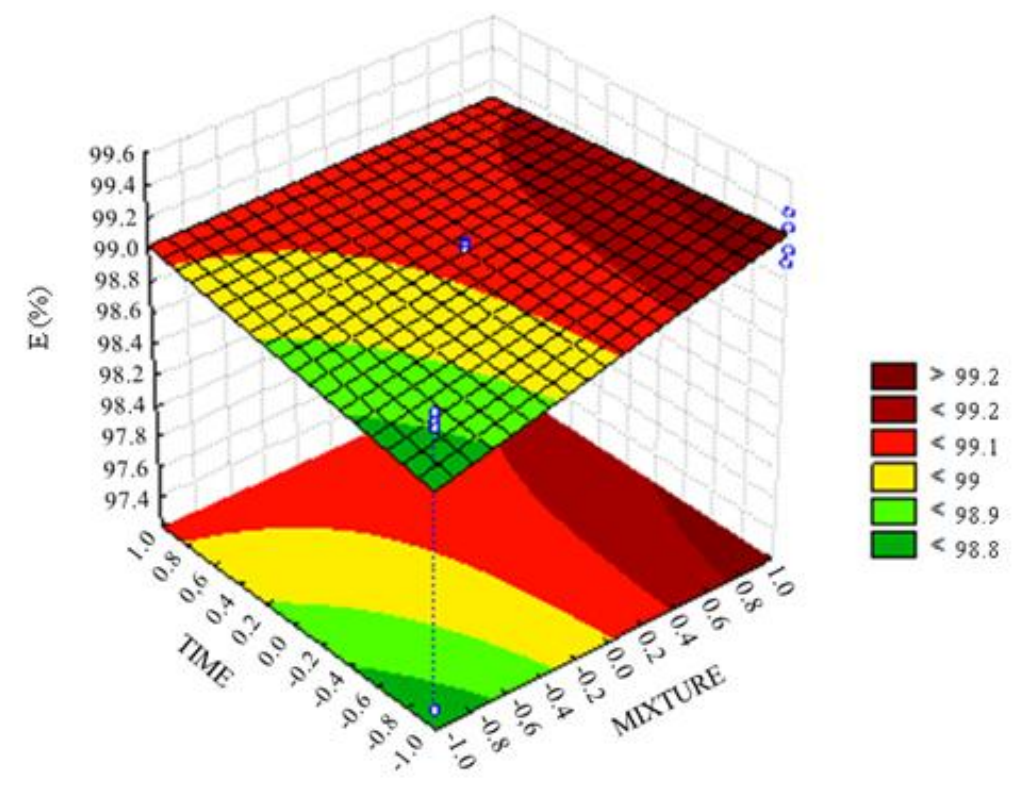

Figure 7. Surface plot of $E(\%)$ as a function of the interactions of time and type of mixture.

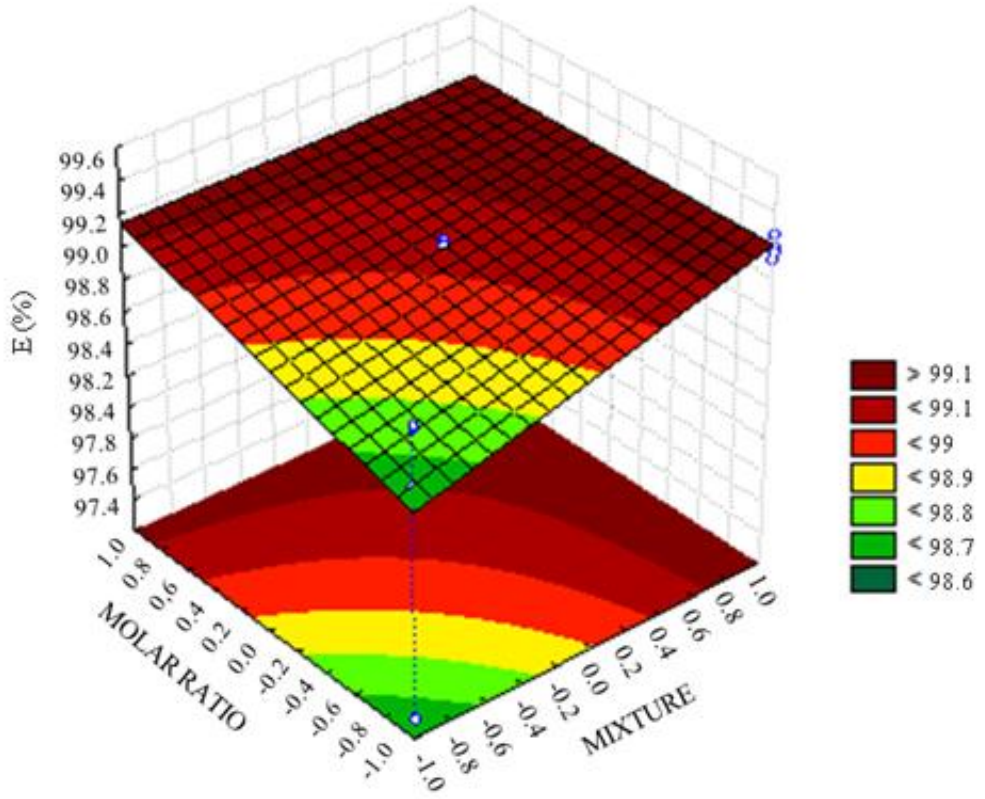

Figure 8. Surface plot of $\mathrm{E}(\%)$ as a function of the interactions of alcohol:oil molar ratio and type of mixture.

yield of $88.4 \%$ with a purity of $99.4 \%$. The authors also concluded that a linear model was sufficient to establish the effect of the variables, and to have a model similar to the one proposed in this work. The molar ratio had a significant and positive influence on the yield, as observed in this work with the mixture.
The best conditions to optimize the two variables studied in biodiesel production, $E$ and $R \%$, were almost the same. Higher values of $R \%$ and $E$, and the best values of viscosity $\left(5.60 \mathrm{~mm}^{2} . \mathrm{s}^{-1}\right)$ were obtained using a mixture of $70 \%$ of frying oil and $30 \%$ of tallow, a low catalyst concentration and higher reaction time (35 seconds). 


\section{CONCLUSIONS}

This research allows the optimization of biodiesel production from blends of frying oil and bovine tallow, using a full factorial design. In the biodiesel production, one could note that all the independent variables influenced the total yields of the reaction. Parameters like alcohol:oil molar ratio of $1: 9,1.5 \%$ of catalyst, 35 seconds of reaction time, and a mixture of $70 / 30$ provided yields above $89 \%$. When analyzing ester content, higher values were obtained when using an alcohol:oil molar ratio of $1: 9,0.5 \%$ of catalyst and a mixture containing $70 \%$ of frying oil and $30 \%$ of bovine tallow, for 35 seconds. Biodiesel was produced with an ester content of $99.43 \%$. Mixtures containing more frying oil and tallow are better, and the best operational time was 35 seconds of reaction.

\section{ACKNOWLEDGEMENTS}

The authors would like to thank Research Support Foundation of Rio de Janeiro (FAPERJ) for the financial support.

\section{REFERENCES}

ANP - Agência Nacional de Petróleo, Gás e Biocombustíveis. Available at: http://www.anp.gov.br. Accessed on: May 2016.

Atapour, M.; Kariminia, H. R.; Moslehabadi, P. M. Optimization of biodiesel production by alkalicatalyzed transesterification of used frying oil. Process Safety and Environmental Protection, v. 92, p. 179-185, 2014.

https://doi.org/10.1016/i.psep.2012.12.005

ASTM D445- American Society for Testing and Materials. Available at: <http://www.astm.org>. Accessed on: May 2016.

Araujo, V. K. W. S.; Hamacher, S.; Seavarda, L. F. Economic assessment of biodiesel production from waste frying oil. Bioresource Technology, v. 101, p. 4415-4422, 2010.

https://doi.org/10.1016/i.biortech.2010.01.101
Azcan, N.; Danisman, A. Microwave Assisted Transesterification of Rapeseed Oil. Fuel, v. 87, p. 1781-1788, 2008.

https://doi.org/10.1016/i.fuel.2007.12.004

Bankovic-lic, I. B.; Stojkovic, I. J.; Stamenkovic, O. S.; Veljkovic, V.B.; Hung, Y. T. Waste animal fats as feedastocks for biodiesel production. Renewable and Sustainable Energy Reviews, v. 32, p. 238-254, 2014.

https://doi.org/10.1016/j.rser.2014.01.038

Charoenchaitrakool, M.; Thienmethangkoon, J. Statistical optimization for biodiesel production from waste frying oil through two-step catalyzed process. Fuel Processing Technology, v. 92, p. 112118, 2011.

https://doi.org/10.1016/i.fuproc.2010.09.012

Demirbas, A. Biodiesel from vegetable oils via transesterification in supercritical methanol. Energy Conversion \& Management, v. 43, p. 23492356, 2002.

https://doi.org/10.1016/S0196-8904(01)00170-4

Felizardo, P.; Correia, M. J. N.; Raposo, I.; Mendes, J. F.; Berkemeir, R.; Bordado, J. M. Production of biodiesel from waste frying oils. Waste Management, v. 26, p. 487-494, 2006. https://doi.org/10.1016/j.wasman.2005.02.025

Fangrui, M.; Hanna, M. A. Biodiesel production: a review. Bioresource Technology, v. 70, p. 1-15, 1999.

Fukuda, H.; Kondo, A.; Noda, H. Biodiesel fuel production by transesterification of oils. Journal of Bioscience and Bioeengineering, v. 92, p. 405-416, 2001. https://doi.org/10.1016/S1389-1723(01)80288-7

Gazzoni, D. L. Matérias-primas para a produção
de biodiesel. Available at at:
<www.biodieselbr.com.br / plants /
oleaginosas.htm>. Accessed on: May 2012.

Issariyakul, T.; Kulkarni, M. G.; Meher, L. C.; Dalai, A. K.; Barkhshi, N. N. Biodiesel production from mixtures of canola oil and used cooking oil. Chemical Engineering Journal, v. 140, p. 77-85, 2008. https://doi.org/10.1016/i.cej.2007.09.008 
Kucek, K. T.; Ramos, L. P.; Oliveira, M. A. F. C.; Wilhelm, H. M. Ethanolysis of refined soybean oil assisted by sodium and potassium hydroxides. Journal of the American Oil Chemists Society, v. 84, p. 385-392, 2007.

https://doi.org/10.1007/s11746-007-1048-2

Lee, H. V.; Yunus, R.; Juan, J. C.; Taufiq-Yap, Y. H. Process optimization design for jatropha-based biodiesel production using response surface methodology. Fuel Processing Technology, v. 92, p. 2420-2428, 2011.

https://doi.org/10.1016/j.fuproc.2011.08.018

Ma, F.; Hanna, M. A. Biodiesel production: a review. Bioresource Technology, v.70, p.1-15, 1999. https://doi.org/10.1016/S0960-8524(99)00025-5

McCormick, R. L.; Graboski, M. S.; Alleman, T. L.; Herring, A. M. Impact of biodiesel source material and chemical structure on emissions of criteria pollutants from a heavy-duty engine. Environmental and Science Technology, v. 35, p. 1742, 2001. https://doi.org/10.1021/es001636t

Mendonça, D. R.; Andrade, H. M. C.; Guimarães, P. R. B.; Vianna, R. F.; Meneghetti, S. M. P.; Pontes, L.A.M.; Teixeira, L. S. G. Application of full factorial design and Doehlert matrix for the optimization of beef tallow methanolysis via homogeneous catalysis. Fuel Processing Technology, v. 92, p. 342348, 2011.

https://doi.org/10.1016/i.fuproc.2010.09.026

Mohammadshirazi, A.; Akram, A.; Rafiee, S.; Kalhor, E.B. Energy and cost analyses of biodiesel production from waste cooking oil. Renewable and Sustainable Energy Reviews, v. 33, p. 44-49, 2014. https://doi.org/10.1016/j.rser.2014.01.067

Moretto, E.; Fett, R. Definition of oils and fats technology vegetable oils and fats in the food industry. São Paulo: Varela, 1998. (in Portuguese)

Moura, B. S. Alkaline transesterification of vegetable oils for biodiesel production: technical and economical evaluation, Dissertação de mestrado, Programa de Pós-Graduação em Engenharia Química, Universidade Federal Rural do Rio de Janeiro, 2010 (in portuguese).
Moura, K. R. M. Optimization of the production process of biodiesel from tallow methyl applying a central composite rotational design (CCRD) and evaluation of thermal stability. $\mathrm{PhD}$ thesis, Federal University of Paraíba, João Pessoa, PB, 2008. (in Portuguese)

Costa Neto, P. R.; Rossi, L. F. S.; Zagonel, G. F.; Ramos, L. P. Produção de biocombustível alternativo ao óleo diesel através da transesterificação de óleo de soja usado em frituras. Química Nova, v. 23, p. 531-537, 2000. (in Portuguese)

Oliveira, L. B. Potencial de aproveitamento energético de lixo e de biodiesel de insumos residuais no Brasil. Tese em Planejamento Energético - Universidade Federal do Rio de Janeiro, COPPE, Rio de Janeiro, 2004. (in Portuguese).

Pereira, F. E. A. Biodiesel produzido a partir do óleo de sementes de Mabea fistulifera Mart.. Dissertação (Mestrado em Agroquímica). Universidade Federal de Viçosa, Minas Gerais, 2007. (in Portuguese).

Rodrigues, M. I.; lemma, A. F. Planejamento de experimentos e otimização de processos. Campinas: Editora Casa do Pão, $1^{\text {st }}$ ed., 2005. (in Portuguese)

SBRT - Brazilian Service Response Techniques. Available at: <http://www.astm.org>. Accessed on: June 2016.

Shin, H. Y.; Lim, S. M.; Kang, S. C.; Bae, S. Y. Statistical optimization for biodiesel production from rapeseed oil via transesterification in supercritical methanol. Fuel Processing Technology, v. 98, p. 1-5, 2012.

https://doi.org/10.1016/j.fuproc.2012.01.025

Silva, C. C. C. M.; Ribeiro, N. F. P.; Souza, M. M. V. M.; Aranda, D. A. G. Biodiesel production from soybean oil and methanol using hidrotalcites as catalyst. Fuel Processing Technology, v. 91, p. 205210, 2010.

https://doi.org/10.1016/j.fuproc.2009.09.019 
SMAOFD - Standard methods for the analysis of oils, fats and derivatives. Boston: International Union of Pure and Applied Chemistry - IUPAC, $7^{\text {st }}$ ed., method 2507, 1987.

Sulistyo, H.; Rahayu, S. S.; Winoto, G.; Suardjaja, I. M. Biodiesel production from high iodine number candlenut oil. World Academy of Science, Engineering and Technology. v. 48, 2008.

Wyatt, V. T.; Hess, M. A.; Dunn, R. O.; Foglia, T. A.; Haas, M. J.; Marmer, W. N. Fuel Properties and Nitrogen Oxide Emission Levels of Biodiesel Produced from Animal Fats. Journal of the American Oil Chemists' Society, v. 82 , p. 585, 2005. https://doi.org/10.1007/s11746-005-1113-2
UBRABRIO - União Brasileira de Biodiesel e Bioquerosene. Available at: <http://www.ubrabio.com.br/1891/noticias/nosest adosunidosbiodieseleutilizadoemmisturasquevao_ 258074/>. Accessed on: March 2016.

Zhang, Y.; Dubé, M. A.; Lean, D.D.; Kates, M. Biodiesel production from waste cooking oil: 2 . Economic assessment and sensitivity analysis. Bioresource Technology, v. 90, p. 229, 2003. https://doi.org/10.1016/S0960-8524(03)00150-0 